\title{
Sectoral oil consumption and economic growth in Pakistan: An ECM approach
}

\author{
Bedi-uz-Zaman, Muhammad Farooq and Sami Ullah \\ Lecturer, Department of Economics, University of Gujrat, Gujrat, Pakistan \\ Email: samigcu@yahoo.com, Cell \#+92-345-6939593
}

\begin{abstract}
This study examines the sectoral oil consumption and its impact on economic growth of Pakistan for the time period of 1972-2008. For this purpose different time series techniques are applied to estimate the relationship. The result shows that major sectors of oil consumption (transportation, power generation and industry) are positively contributing, while the minor sectors of oil consumption (household, government and agriculture) are negatively contributing in economic growth. Stability of the model is checked by error correction model, which explain that model used in this study is stable and all the variables are contributing in stability of model. Traditional granger causality test shows that there is uni-directional causal relationship between real GDP, transport sector and industrial sector with power sector in Pakistan.
\end{abstract}

Keywords: Oil Consumption, ECM Approach, Pakistan

\section{INTRODUCTION}

Oil is one of the critical factors in sustaining the economic growth and welfare of oil importing countries like Pakistan. Especially, in the era of globalization, a rapidly increasing demand for overall energy and dependency of countries indicate that energy will be one of the biggest problems in the world in this century. As the main focus of traditional growth theories is on the labour and capital as major factor of production while it ignores the importance of energy in the growth process (Stern and Cleveland, 2004). Research also suggests that energy plays an important role as compared to other variables included in the production and consumption function for countries which are at intermediate stages of economic development (IEA, 2005).

The decisions taken by different groups of society, regarding the use of energy have very important implications for long-run as well as short-run changes in social and economic performance of any economy. The nature of overall and sectoral oil consumption are of vital importance for precise forecasting of its current and future needs. For this purpose it is necessary to examine the relationship between sectoral oil consumption and economic growth for Pakistan.

The relationship between oil consumption and economic growth has important implications at the hypothetical, practical and policy level. A large number of studies have focused on the relationship between energy consumption and real GDP. The impacts of all sources of energy were not same on economic growth. The impact of electricity and petroleum products were high and significant on economic growth with reverse causality between petroleum products and economic growth (Siddiqui, 2004). However, to date the results are conflicting and no considerable work is done on sectoral energy consumption, particularly sectoral oil consumption. It is very productive to work with this idea, which is implicitly presented in Siddiqui work, because we are consuming a lot of oil in almost all sectors of the economy, especially in transportation, power generation and industry. Pakistan having best irrigated system but we are still producing electricity by using oil. So this study investigates sectoral share of oil consumption in power generation, industry, transport, household, agriculture and government level because different sectors having different consumption patterns and how each sector effect the overall performance of the economy.

During and after 1980's, various studies have been conducted to investigate the relationship between overall energy consumption and economic growth, the result show that there is a strong relationship between energy consumption and economic growth. As, Fatai et al. (2004), Stern (1993, 2000), Yu and Choi (1985), Soytas and Sari (2003), Asafu-Adjaye (2000), Wolde-Rufael (2004) and Lee (2005) found supportive evidence of causality running from energy consumption to income. On the other hand, many 
researchers have investigated that the relationship between energy-income may be characterized bidirectional causality. Siddiqui (2004) found that the impact of all sources of energy were not same on economic growth. The impact of electricity and petroleum products were high and significant on economic growth with reverse causality between petroleum products and economic growth. Ghosh (2002), and Mozumder and Marathe (2007) found unidirectional causality successively from GNP to energy consumption. Shiu and Lam (2004) reported unidirectional causality exists from energy consumption to GNP. Jumbe (2004) found bidirectional causality between energy consumption and GNP. Erol and Yu (1987) examined the relationship between energy consumption and GDP for England, France, Italy, Germany, Canada and Japan with the data of 1952-1982 period and the causality relationships they found were bidirectional for Japan, unidirectional from energy consumption to GDP for Canada, Germany and Italy. They could not find any causality for France and England. Yang (2000) found unidirectional causality running from economic growth to coal consumption in Taiwan.
Recently, Yoo (2006) found unidirectional long-run causality from economic growth to coal consumption, and bidirectional strong causality from coal consumption to economic growth in Korea.

Sectoral Oil Consumption in Pakistan: Overall world scenario during 2008-09 is very severe due to international fluctuations in oil prices. All oil importing countries like Pakistan are under stress due to increased oil prices and major cavity in macroeconomic indicators as, inflation, budgetary deficit, current account deficit, exchange rate volatility, fluctuations in foreign exchange reserves and decreased purchasing power of the poor class. There are two major reasons behind this scenario of overall slow down of Pakistan economy, first demand contraction policies of the government of pakistan and secondly, international financial crises. These two forces effected the Energy consumption and industrial sector of Pakistan. All forms of energy declined or at least remain stagnant during the fiscal year 2008-09. Figure 1 below express the energy mix in 2007-08, where oil accounts for 29 percent of the total energy used.

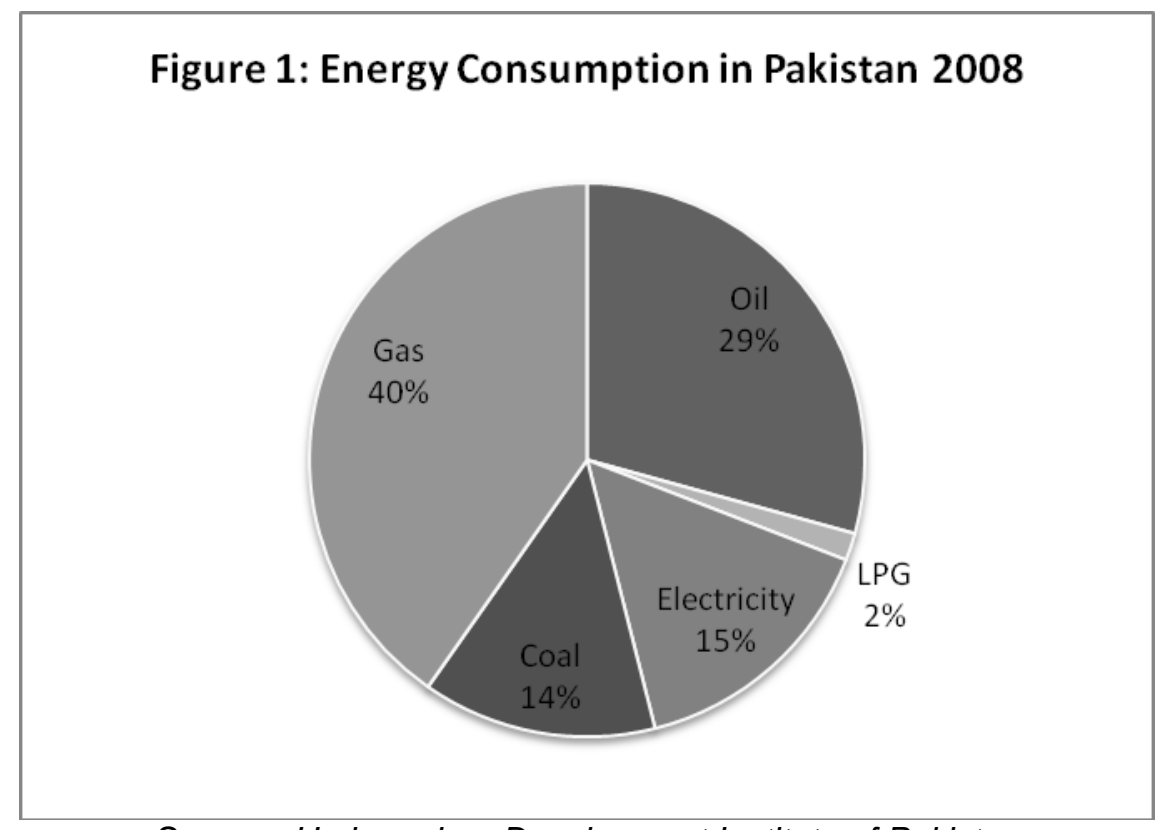

Source: Hydrocarbon Development Institute of Pakistan

Fig 1 shows that share of oil in overall energy consumption is $\mathbf{2 9 . 3}$ percent, while the oil share was $\mathbf{4 8}$ percent in 1996-97. On the other hand the share of coal and gas increased from $6 \%$ to $13.7 \%$ and $29 \%$ to $40.3 \%$, respectively.

The sectoral consumption of oil/petroleum products increased in power generation and government sector, while oil consumption in all other sectors is decreased in 2008-09 as compared to previous year.
As figure 2 shows sectoral share of oil consumption in Pakistan, the major portion of oil is consumed in transportation which is $51.92 \%, 39.18 \%$ in power generation, $5.92 \%$ in industrial sector, while 
government, household and agriculture sector consume only $1.72 \%, 0.67 \%$ and $0.60 \%$ respectively.

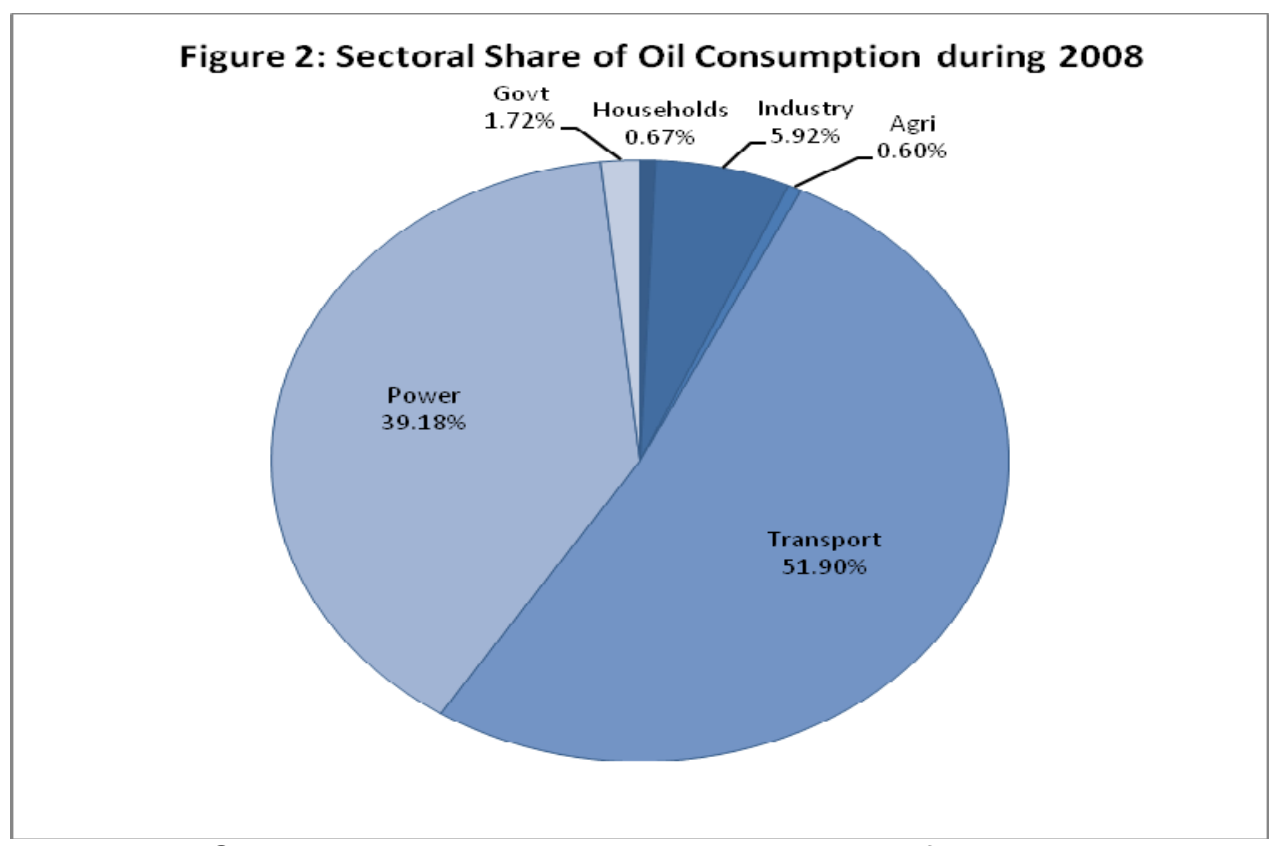

Source: Hydrocarbon Development Institute of Pakistan

Table 1 presents overall oil consumption and percentage change in consumption in different sectors for previous ten years. This table also shows that major share of oil is utilized in transportation, power generation and industry, while minor share of oil is consumed in agriculture, household and by government.

Table 1: Sectoral Consumption of Oil/Petroleum Products (000 tones)

\begin{tabular}{|c|c|c|c|c|c|c|c|c|c|c|c|c|c|}
\hline Year & $\begin{array}{c}\begin{array}{c}\text { House } \\
\text { holds }\end{array} \\
\end{array}$ & $\begin{array}{c}\% \\
\text { Change } \\
\end{array}$ & Industry & $\begin{array}{c}\% \\
\text { Change } \\
\end{array}$ & $\begin{array}{c}\begin{array}{c}\text { Agricultu } \\
\text { re }\end{array} \\
\end{array}$ & $\begin{array}{c}\% \\
\text { Change } \\
\end{array}$ & $\begin{array}{c}\begin{array}{c}\text { Trans- } \\
\text { port }\end{array} \\
\end{array}$ & $\begin{array}{c}\% \\
\text { Change } \\
\end{array}$ & Power & $\begin{array}{c}\% \\
\text { Change }\end{array}$ & $\begin{array}{l}\text { Other } \\
\text { Govt. }\end{array}$ & $\begin{array}{c}\% \\
\text { Change } \\
\end{array}$ & Total \\
\hline 1996-97 & 510 & -14.4 & 2,141 & -11.4 & 269 & 7.6 & 7,172 & 0.5 & 5,110 & 6.8 & 404 & -3.2 & 15,606 \\
\hline 1997-98 & 499 & -2.2 & 2,081 & -2.8 & 245 & -8.9 & 7,364 & 2.7 & 6,054 & 18.5 & 381 & -5.7 & 16,624 \\
\hline 1998-99 & 493 & -1.2 & 2,140 & 2.8 & 249 & 1.6 & 7,864 & 6.8 & 5,526 & -8.7 & 376 & -1.3 & 16,648 \\
\hline 1999-00 & 477 & -3.2 & 2,116 & -1.1 & 293 & 17.8 & 8,308 & 5.6 & 6,228 & 12.7 & 346 & -8.0 & 17,768 \\
\hline 2000-01 & 451 & -5.5 & 1,924 & -9.1 & 255 & -13.0 & 8,158 & -1.8 & 6,488 & 4.2 & 372 & 7.5 & 17,648 \\
\hline 2001-02 & 335 & -25.7 & 1,612 & -16.2 & 226 & -11.4 & 8,019 & -1.7 & 6,305 & -2.8 & 464 & 24.7 & 16,960 \\
\hline 2002-03 & 283 & -15.5 & 1,604 & -0.5 & 197 & -12.8 & 8,082 & 0.8 & 6,020 & -4.5 & 266 & -42.7 & 16,452 \\
\hline 2003-04 & 231 & $\begin{array}{l}-18.4 \\
\end{array}$ & 1,493 & -6.9 & 184 & -6.6 & 8,464 & 4.7 & 2,740 & -54.5 & 309 & 16.2 & 13,421 \\
\hline 2004-05 & 193 & -16.5 & 1,542 & 3.3 & 142 & -22.8 & 9,025 & 6.6 & 3,452 & 26.0 & 317 & 2.6 & 14,671 \\
\hline 2005-06 & 129 & -33.2 & 1,681 & 9.1 & 82 & -42.3 & 8,157 & -9.6 & 4,219 & 22.2 & 358 & 13.0 & 14,627 \\
\hline 2006-07 & 106 & -17.8 & 1,569 & -5.1 & 97 & 18.3 & 7,982 & -2.1 & 6,741 & 59.8 & 325 & -9.5 & 16,847 \\
\hline 2007-08 & 121 & 14.1 & 1,071 & -32.9 & 109 & 12.7 & 9,384 & 17.6 & 7,084 & 5.1 & 311 & -4.5 & 18,080 \\
\hline
\end{tabular}




\section{Methodology and Data}

The variables used in this study of sectoral oil consumption and economic growth of Pakistan are real gross domestic product (RGDP) as dependent variable, and sectoral share of oil consumption in transportation (TRANS), power generation (POW), industry (IND), agriculture (AGRI), government (GOVT) and by household $(\mathrm{HH})$, as independent variable. The sample period covers annual data from 1972 to 2008. All the relevant data is obtained from International Financial Statistics (IFS), Pakistan Economic Survey and Hydrocarbon Development Institute of Pakistan. The GDP deflator (on the basis of 2000) is used as price deflator for nominal GDP series to deflate the inflationary effect. All the variables are given in log form.

Many economic time series are non-stationary at levels. One way of getting the interesting information about the stationarity of time series is to plot the original series and making correlogram at both level and first difference. The second, most rigorous way is to use the Augmented Dickey Fuller (ADF) which is the wider version of the standard Dickey Fuller (DF). This test is employed to verify the presence of unit root in the series.

Given a simple AR (1) process

$$
z_{t}=\rho z_{t-1}+x_{t}^{\prime} \tau+\varepsilon_{t}
$$

where, $z_{t}$ is a time series, $x_{t}$ represents exogenous regressors which is optional in the model, $\rho$ and $\tau$ are the parameters to be estimated and $\varepsilon_{t}$ is the white noise. To employ the standard DF test, the term $Z_{t-1}$ is subtracted from both sides of (1) and then ordinary least square (OLS) estimation method is employed on (2).

$$
\Delta z_{t}=\alpha z_{t-1}+x_{t}^{\prime} \tau+\varepsilon_{t}
$$

Where $\Delta$ is the first difference operator, $\alpha=\rho-1$, and $\varepsilon_{t}$ is the error such that $\varepsilon_{t} \square$ i.i.n $\left(0, \sigma_{\varepsilon}^{2}\right)$ The rejection of the hypothesis $H_{0}: \alpha=0(\rho=1)$ explains that $y_{t}$ is nonstationary series and its variance increases with time. This is also an indication that the differences are needed to achieve stationarity. One problem with DF test of unit root is that the assumption of white noise is violated if the series is correlated at higher order lags. In such circumstances, augmented Dickey Fuller (ADF) is one possible solution of the problem. It employed lagged differences of the series $Z_{t}$ among the regressors to correct for higher order correlation. In other words, the ADF test "augments" the traditional DF test assuming that the $\mathrm{z}$ series is a $A R(p)$ process, and therefore, adding $p$ lagged difference terms of the dependent variables to the right hand side of regression of (2)

$$
\Delta z_{t}=\alpha z_{t-1}+x_{t}^{\prime} \tau+\sum_{i=1}^{p} \phi_{i} \Delta z_{t-i}+v_{t}
$$

Mostly in time series data analysis our concern is to investigate the long run dynamics relationship among the variables. Engle and Granger (1987) stated that two non-stationary time series are said to be cointegrated if their linear combination is stationary. The stationary linear combination is called the cointegrating equation and may be interpreted as a long-run equilibrium relationship among the variables. Engle and Granger cointegration test is for two time series variables while for multiple time series, cointegration test is implemented through Johansen and Jeselius (1990) approach. This method involves estimating the following unrestricted vector autoregressive (VAR) model.

$$
z_{t}=A_{0}+\sum_{j=1}^{p} A_{j} z_{t-j}+\varepsilon_{t}
$$

Where $z_{t}$ is an $n \times 1$ vector of non-stationary I(1) variable, $A_{0}$ is a $n \times 1$ vector of constants, $p$ is the lag order, $A_{j}$ is a $n \times n$ matrix of estimable parameters, and $\varepsilon_{t}$ is $n \times 1$ vector of independent and identically distributed error terms.

The VAR may be written as

$$
\Delta z_{t}=A_{0}+\sum_{j=1}^{p-1} \Gamma_{j} z_{t-j}+\Pi z_{t-1}+\stackrel{(2)}{c_{t}}
$$

Where $\Gamma_{j}=-\sum_{i=j+1}^{p} A_{i}$ and $\Pi=\sum_{j=1}^{p} A_{j}-I$,

$\Delta$ is the difference operator, and $I$ is an $n \times n$ identity matrix.

The number of cointegration vectors is determined by the rank of matrix $\Pi$ which states the number of independent cointegration. If the rank of $\Pi$ equals $r$ and $r<n$ then there exists $r$ cointegrating vectors in the model (5). 
The causal relationship between time series is checked through Granger causality test, developed by Granger (1969). According to Granger, a variable $X_{t}$ is said to be Granger cause another variable $z_{t}$ if the past and present values of $x_{t}$ helps to predict $z_{t}$. The evaluation of following regressions leads to estimate the causality relationship among the time series:

$$
\begin{gathered}
z_{t}=\sum_{j=1}^{p} \delta_{1 j} z_{t-j}+\sum_{j=1}^{p} \theta_{1 j} x_{t-j}+\mu_{1 t} \\
x_{t}=\sum_{j=1}^{p} \delta_{2 j} z_{t-j}+\sum_{j=1}^{p} \theta_{2 j} x_{t-j}+\mu_{2 t}
\end{gathered}
$$

The null hypothesis $H_{0}: \theta_{1 j}=0, j=1,2, \cdots p$, states that $x_{t}$ does not Granger cause $z_{t}$; and $H_{0}: \delta_{2 j}=0, j=1,2, \cdots p$, that $z_{t}$ does not Granger cause $x_{t}$. The non-rejection of both of above two hypotheses employs that there is no causal relationship between the variables. In other words, two variables are independent to each others. The rejection of one hypothesis indicates that there is unidirectional causality between the variables. And if both the hypothesis is rejected then it is the indication of bidirectional causality.

The traditional Granger causality test uses the simple F-test and this test becomes insufficient to determine the causality if the time series included in the analysis are I(1) and cointegrated. Several studies [such as Engle and Granger (1987), Toda and Yamamoto (1995), Ahmad and Harnhirun (1996) Tsen (2006)] support this statement. In such circumstance, the
Granger causality should be tested through ECM by estimating following equation:

$$
\begin{gathered}
\Delta z_{t-1}=\sum_{j=1}^{p} \delta_{1 j} \Delta z_{t-j}+\sum_{j=1}^{p} \theta_{1 j} \Delta x_{t-j}+\phi_{1} \varepsilon_{1 t-1}+\mu_{1 t} \\
\Delta x_{t-1}=\sum_{j=1}^{p} \delta_{2 j} \Delta z_{t-j}+\sum_{j=1}^{p} \theta_{2 j} \Delta x_{t-j}+\phi_{2} \varepsilon_{2 t-1}+\mu_{2 t}
\end{gathered}
$$

Where $\varepsilon_{1 t-1}$ and $\varepsilon_{1 t-2}$ are the lagged values of the error terms from the following equations:

$$
\begin{aligned}
& x_{t}=\eta_{1}+\theta_{1} y_{t}+\varepsilon_{1 t} \\
& x_{t}=\eta_{2}+\theta_{2} y_{t}+\varepsilon_{2 t}
\end{aligned}
$$
After inclusion of the error terms from cc (7) ation
regression in the ECM equations, the causality relationship between the series can be evaluated either through the traditional F-test for the joint significance of the parameters $\theta_{1 j}$ and $\delta_{2 j}$ or through the significance of $\phi_{1}$ and $\phi_{2}$.

\section{RESULTS AND DISCUSSIONS}

In Table 1 shows the stationarity of the variables. As literature suggest that most of the economic variables are non-stationary at their level. This situation exists in this table because all the variables are nonstationary in their levels because $p>0.05$. and stationary in their first differences because $p<0.05$.It shows that the variables are I(1). This phenomenon can also be checked by comparing the value of test statistics and the critical value at $5 \%$ level of significance that are 2.9458 and 2.9484 for the level and the differenced series.

Table 1: Unit Root Test for Pakistan

\begin{tabular}{|l|c|c|c|c|}
\hline & \multicolumn{2}{|c|}{ Levels } & \multicolumn{2}{c|}{ First Difference } \\
\hline & Test Statistics & p-values & Test Statistics & p-value \\
\hline Log(RGDP) & -1.0358 & 0.7291 & -4.8061 & 0.0005 \\
\hline Log(AGR) & -1.0678 & 0.7178 & -5.8227 & 0.0000 \\
Log(GOVT) & -1.8124 & 0.3687 & -7.6604 & 0.0000 \\
\hline Log(HH) & 1.1297 & 0.9970 & -3.7151 & 0.0081 \\
\hline Log(IND) & -1.2412 & 0.6457 & -3.3358 & 0.0207 \\
\hline Log(POW) & -1.1423 & 0.6882 & -4.2205 & 0.0022 \\
Log(TRANS) & -2.9367 & 0.0510 & -4.2997 & 0.0017 \\
\hline
\end{tabular}

Note: All the variables for Pakistan are stationary at their first differences and $5 \%$ level of significance is used. Absolute critical values at $5 \%$ are 2.9458 and 2.9484 for level and first differenced stationary series. 
Table 2: Cointegrating Trace Statistics and Eigen Values for Pakistan

\begin{tabular}{|c|c|c|c|c|c|c|}
\hline $\begin{array}{l}\text { Null } \\
\text { Alternative }\end{array}$ & $\begin{array}{l}r=0 \\
r \geq 1\end{array}$ & $\begin{array}{l}r \leq 1 \\
r \geq 2\end{array}$ & $\begin{array}{l}r \leq 2 \\
r \geq 3\end{array}$ & $\begin{array}{l}r \leq 3 \\
r \geq 4\end{array}$ & $\begin{array}{l}r \leq 4 \\
r \geq 5\end{array}$ & $\begin{array}{l}r \leq 5 \\
r \geq 6\end{array}$ \\
\hline Trace Statistics & 334.7764 & 196.8237 & 124.0605 & 63.6470 & 31.8846 & 11.4705 \\
\hline Eigen Value & 0.9866 & 0.8971 & 0.8486 & 0.6294 & 0.4716 & 0.2928 \\
\hline Critical Value & 125.6154 & 95.75366 & 69.81889 & 47.85613 & 29.79707 & 15.49471 \\
\hline Probability & 0.0000 & 0.0000 & 0.0000 & 0.0009 & 0.0283 & 0.1842 \\
\hline
\end{tabular}

The next step is to find the cointegrating equations which will tell whether there exists long run relationship between the variables or not. Two methods are usually employed to check the number of cointegrating equations; first one is Trace test statistics and second one is eigen values. Trace test statistic is used to determine the number of cointegrating equations. Table 2 shows that the value of Trace test statistic is greater than that of critical value up to the five cointegrating equations. The $p$ value also indicate that five cointegrating equation exist $(p<0.05)$.

$$
\begin{aligned}
& L R G D P=0.0555 L P O W+0.0268 L I N D-0.0289 L H H-0.1199 L G O V T-0.1235 L A G R+0.5235 L T R A N S \\
& \begin{array}{llllll}
(0.0024) & (0.0081) & (0.0027) & (0.0058)
\end{array}
\end{aligned}
$$

The cointegrating equation is presented above shows that some variable positively contributing in real GDP like power generation, industry sector and transport sector. These sectors are the main consumer of oil because they are consuming $97 \%$ of the total oil consumptions.. This can be checked by looking into sectoral share of the different sector consuming oil. The other variables like Household sector,
Government sector and Agriculture sector have negative contribution in real GDP and these sectors are just consuming $3 \%$ of the total oil consumption.

The standard error of the coefficients is given in parentheses. The results shows that all the variables are significant because if coefficients are divided by their respective standard error. The result will be greater than 2.00 .

Table 3: Traditional Granger Causality Test for Pakistan

\begin{tabular}{|lcc|}
\hline Hypothesis & F-Statistic & Probability \\
\hline Ho: LPOW does not Granger Cause LRGDP & 1.2039 & 0.3141 \\
H1: LRGDP does not Granger Cause LPOW & 3.8521 & 0.0324 \\
\hline Ho: LIND does not Granger Cause LRGDP & 1.1624 & 0.3264 \\
H1: LRGDP does not Granger Cause LIND & 1.0390 & 0.3662 \\
\hline Ho: LTRANS does not Granger Cause LRGDP & 1.8662 & 0.1722 \\
H1: LRGDP does not Granger Cause LTRANS & 1.3021 & 0.2869 \\
\hline Ho: LIND does not Granger Cause LPOW & 8.2604 & 0.0014 \\
H1: LPOW does not Granger Cause LIND & 0.1257 & 0.8824 \\
\hline Ho: LTRANS does not Granger Cause LPOW & 4.7416 & 0.0162 \\
H1: LPOW does not Granger Cause LTRANS & 0.3213 & 0.7277 \\
\hline Ho: LTRANS does not Granger Cause LIND & 0.4555 & 0.6384 \\
H1: LIND does not Granger Cause LTRANS & 0.2221 & 0.8021 \\
\hline
\end{tabular}

Table 3 shows the causal relationship between four main variable, dependent variable real GDP and independent variables; power sector, industrial sector and transportation sector. Traditional causality test is employed which shows that there is uni-directional causal relationship between real GDP, transport sector and industrial sector with power sector. 
Table 4: Vector Error Correction (VEC) Model for Pakistan

\begin{tabular}{|l|c|c|c|c|c|c|c|}
\hline & DLRGDP & DLTRANS & DLPOW & DLIND & DLHH & DLGOVT & DLAGR \\
\hline Constant & 0.0363 & 0.0673 & -0.0967 & -0.0210 & -0.0054 & -0.0912 & -0.0222 \\
& $(0.0097)$ & $(0.0268)$ & $(0.2566)$ & $(0.0669)[-$ & $(0.0526)[-$ & $(0.1084)$ \\
& {$[3.7492]$} & {$[2.5063]$} & {$[-0.3768]$} & $0.3143]$ & $0.1030]$ & {$[-0.8411]$} & $0.2946]$ \\
& & & & & & \\
& & & & & & \\
& -0.0049 & -0.0430 & -0.3009 & -0.1247 & -0.1606 & -0.0079 & -0.1502 \\
& $(0.0074)[-$ & $(0.0205)[-$ & $(0.1963)$ & $(0.0512)$ & $(0.0402)[-$ & $(0.0830)$ & $(0.0577)[-$ \\
& $0.6611]$ & $2.0942]$ & {$[-1.5325]$} & {$[-2.4365]$} & $3.9916]$ & {$[-0.0956]$} & $2.6025]$ \\
\hline$R^{2}$ & 0.3080 & 0.2652 & 0.3596 & 0.4626 & 0.6808 & 0.1581 & 0.5327 \\
\hline S.E. of Eq & 0.0192 & 0.0533 & 0.5094 & 0.1327 & 0.1044 & 0.2153 & 0.1498 \\
\hline F-Statistics & 1.1376 & 0.9225 & 1.4353 & 2.1995 & 5.4504 & 0.4800 & 2.9135 \\
\hline
\end{tabular}

Note: Values in parentheses show standard error while values in [ ] shows t-values.

Next step in the methodology to check whether the equilibrium is stable or not? If the equilibrium is stable, what is the rate of long run adjustment? Error correction model also verify the results that there is long run relationships between the variable are not. If the sign of error correction term is negative it means there is long run relationship between the variables. And the sign of individual variable's error correction term shows whether the individual variables will make the equilibrium convergent or divergent. The negative sign of individual variable error correction term indicate the convergence of the variable towards equilibrium. Table 4 shows all variables are making equilibrium convergent. The value of error correction term is -0.020082 shows overall model convergence towards equilibrium and the rate of adjustment is about $2 \%$ which is highly significant, $|t|=15.3866$.

Conclusion: This paper is first attempt to investigate the relationship between economic growth and consumption of oil/petroleum in different sectors of the economy of Pakistan. For this purpose different time series techniques are applied to estimate the relationship. All the variables used in this study are stationary in their first differences and there exists long run relationship between the entire variable, checked by trace statistic. Cointegrating equation is estimated which shows that major sectors of oil consumption (transportation, power generation and industry) are positively contributing in economic growth, while the minor sectors of oil consumption (household, government and agriculture) are negatively contributing in economic growth. Stability of the model is checked by vector error correction model, which explain that model used in this study is stable and all the variables are contributing in stability of model. Causal relationship between major contributing sectors of oil consumption and economic growth is also checked by traditional granger causality test which shows that there is uni-directional causal relationship between real GDP, transport sector and industrial sector with power sector in Pakistan.

\section{REFERENCES}

Ahmad, J. and Harnhirun, S., (1996), "Cointegration and Causality between Exports and Economic Growth: Evidence from the ASEAN Countries", The Canadian Journal of Economics, Vol 29.

Aqeel, A and M.S. Butt, (2001), "The Relationship between Energy Consumption and Economic Growth in Pakistan", Asia-Pacific Development Journal, Vol. 8, No. 2, pp. 101-109

Asafu-Adjaye, J. (2000), "The Relationship between Energy Consumption, Energy Prices and Economic Growth: Time Series Evidence from Asian Developing Countries", Energy Economics, Vol. 22, pp. 615-625.

Engle, R.F, and C.W.J. Granger, (1987), "Cointegration and Error-Correction: Representation, Estimation, and Testing", Econometrica, Vol. 55, pp. 251-276.

Erol, U. and E. H. S. Yu, (1987), "On the Causal Relationship between Energy and Income for Industrialized Countries", Journal of Energy and Development, Vol. 13, pp. 113-122.

Fatai, K., Oxley and F.G. Scrimgeour, (2004), "Modelling the Causal Relationship between Energy Consumption and GDP in New Zealand, Australia, India, Indonesia, The Philippines and Thailand", Mathematics and Computer Simulation, Vol. 64, pp. 431-445.

Ghosh, S. (2002), "Electricity Consumption and Economic Growth in India", Energy Policy, Vol. 30, pp. 125-129

Granger, C. W. J., (1969), "Investigating the Causal Relations by Econometric Models and Cross-Spectral Methods", Econometrica, Vol 37(3).

International Energy Agency (IEA), Statistics Oil Information 2005.

Johansen, S. and K. Juselius, (1990), "Maximum Likelihood Estimation and Inference on Cointegration-With 
Application to Demand for Money", Oxford Bulletin of Economic and Statistics, Vol. 52, pp. 169-210.

Jumbe, C.B.L. (2004), "Cointegration and Causality between Electricity Consumption and GDP: Empirical Evidence from Malawi", Energy Economics, Vol. 26, pp. 61-68.

Khan, M. A, and Usman Ahmed, (2008), Energy Demand in Pakistan: A Disaggregate Analysis, MPRA Paper No. 15369.

Kraft, J and A. Kraft, (1978), "Note and Comments: On the Relationship between Energy and GNP", The Journal of Energy and Development, Vol. 3, pp. 402-403.

Lee, C. C. (2005), Energy Consumption and GDP in Developing Countries: A Cointegrated Panel Analysis", Energy Economics, Vol. 27, pp. 415-427.

Mozumder, P. Marathe, A. (2007), "Causality relationship between electricity consumption and GDP in Bangladesh", Energy Policy, 35 (1) pp.395402.

Sari, R., B. T. Ewing and U. Soytas, (2008), "The Relationship Between Disaggregate Energy Consumption and Industrial Production in the United States: An ARDL Approach", Energy Economics, Vol. 30, pp. 2302-2313.

Siddiqui, R. (2004), "Energy and Economic Growth in Pakistan", The Pakistan Development Review, Vol. 43, No. 2, pp. $175-200$.

Soytas, U. and R. Sari, (2003), "Energy Consumption and GDP: Causality Relationship in G-7 Countries and Emerging Markets", Energy Economics, Vol. 25, pp. 33-37.
Stern, D. I. (1993), "Energy and Economic Growth in the USA, A Multivariate Approach", Energy Economics, Vol. 15, pp. 137-150.

Stern, D. I. (2000), "A Multivariate Cointegration Analysis of the Role of Energy in the US Economy", Energy Economics, Vol. 22, pp. 267-283

Stern, D. I. and J. C. Cleveland, (2004), "Energy and Economic Growth", Rensselaer Working Papers in Economics, ss. 1-42

Toda, H. Y. and Yamamoto, T., (1995), "Statistical Inference in Vector Autoregressions with Possibly Integrated Processes", Journal of econometrics, Vol 66.

Tsen, W. H., (2006), "Granger Causality Tests among Openness to International Trade, Human Capital Accumulation and Economic Growth in China: 19521999", International Economic Journal, Vol 20(3).

Wolde-Rufael, Y. (2004), "Disaggregate Energy Consumption and GDP, the Experience of Shangai 1952-1999", Energy Economics, Vol. 26, pp. 69-75.

Yang, H.Y. (2000), "Coal Consumption and Economic Growth in Taiwan", Energy Sources, 22, pp. 109-115.

Yoo, S.H. (2006), "Causal relationship between coal consumption and economic growth in Korea", Applied Energy , 83, pp. 1181-1189

Yu, E.S.H. and J.Y. Choi, (1985), "The Causal Relationship between Energy and GNP: An International Comparison", Journal of Energy Development, Vol. 10, pp. 249-272. 